http://www.jfas.info

\title{
STUDYING THE ELECTRONIC CUSTOMER RELATIONSHIP MANAGEMENT AND ITS EFFECT ON BANK QUALITY OUTCOMES
}

\author{
M. G. Farahani*, A. M. Eaidivandi, Z. H. Rad \\ Young Researchers and Elite club, Arak Branch, Islamic Azad University, Arak, Iran
}

Published online: 16 July 2016

\begin{abstract}
In this article, the researcher attempts to study theelectronic customerrelationship management and its effect on bank quality outcomes. Statistical population of thus research is all staff working at Refah Bank of Arak City. The research objective is applied and the method is survey-descriptive. The researcher has used questionnaire to collect the data in addition to library references. Sampling size is 122 based on Cochran's formula that was returned after distributing of 80 samples. Hypotheses of research have been analyzed using spss software and Spearman correlation test. The results prove all hypotheses of research.
\end{abstract}

Keywords: Electronic Banking, Service Quality, Customer Satisfaction, Management of Relationship with Customer, Commitment

Author Correspondence, e-mail: Mghiyasi1983@yahoo.com

doi: http://dx.doi.org/10.4314/jfas.v8i2s.109

\section{INTRODUCTION}

In today hyper competition era, not any organization can achieve to success without paying attention to the customers' needs and demands and their satisfaction. Service quality is so important because it focuses on reduction of costs, increasing of satisfaction, customer retention, increasing of profitability and word of mouth advertising. 
The organization must be aware of customers' expectations to achieve such interests, identify the problems with warning mechanism and responding to them appropriately. To most experts, the surest way to succeed is offering good services to the customers. This is obtained through productions and services with good quality (Zeithaml\&Parasuraman, 2008, 9). The companies with high level of customer satisfaction always are more powerful and successful in long time. According to this, understanding the main capabilities, competitive advantages of studying and comparing the organizational performance from customers' view and determine the index of customer satisfaction have undeniable importance and necessity (Nayebzade\&Fathi, 2009, 117).

This article studies the impact of e-customer relationship management system in banking industry from the customer's view. Since the most e-CRM implementations are not directly observed andunderstand by customer, it is used interviews with experts in banking industry to develop a new structure called "service features based on customer" that study the impact of e-CRM from customer's view.In this research, the researcher tries to study theelectronic customer relationship management and its effect on bank quality outcomes.

\section{Theoretical framework and conceptual model}

Sheng (2002), offers a theory with main subjects about attracting and maintaining the customer that led to profitability. In this article, the researcher attempts to study theelectronic customer relationship management and its effect on bank quality outcomes using a similar research done by Sivarax and et al. in 2011.

\section{Theories}

1- e-CRM implementationobviously has a positive relationship with features of customerbased services.

1-1 e-CRM implementationobviously has a positive relationship with the information received by customer.

1-2 e-CRM implementationobviously has a positive relationship with customer communication channels.

1-3e-CRM implementationobviously has a positive relationship with customer's comfort.

2- e-CRM implementationobviously has a positive relationship with quality and outcomes of bank-customer relationship.

2-1 e-CRM implementationobviously has a positive relationship with general quality of bankcustomer relationship.

2-2 e-CRM implementationobviously has a positive relationship with customer's confidence. 
2-3 e-CRM implementationobviously has a positive relationship withcustomer's satisfaction.

2-4 e-CRM implementationobviously has a positive relationship withcustomer's commitment.

2-5 e-CRM implementationobviously has a positive relationship withcustomer's loyalty.

2-6 e-CRM implementationobviously has a positive relationship withcustomer's recommendation (will).

3- e-CRM implementation has an indirectly effect on quality-revenue relationship through features of customer-based services.

\section{Research key words and concepts}

Service Quality: in marketing literature, service quality is considered as the customer'sgeneral assessment. Generally, understanding of service quality caused by comparing the customers' expectations of services and their understanding after experiencing of services (Rasheed \&Latif, 2011; 61).

Parasorman and et al. believe that the customers measure the quality service based on components such as confidence, responding, competency, availability, and goodwill and touchable. (Toyin\& et al. 2008; 36).

\section{Electronic commerce}

Electronic commerce is defined as all commercial exchanges and informing and market processes which is done through electronic methods such as social networks, internet sites, mobile networks and etc. (Shin Ping 2008, 1010). As a simple definition, Electronic commerce can be defined as any commercial and business affairs done online and internet international network (Doherty \& Chadwick 2008; 1247).

Electronic Banking:Electronicbanking is defined as development of products and services with low cost through electronic channels. These products and services can include bill issuance, giving loan, deposits management, electronic payments (Faroughian et al. 2011, 68).

Customer's Satisfaction:Customer's satisfaction is desirability level that customer understands because of the various features. It is a profitability source and a reason for continuing the organization activities (Faroughian et al. 2011, 279).

E-CRM:it defines as technological element CRM that customers can understand and observe through their communication with bank. It includes both operational and analytical e-CRM (Sivarax and et al. 2011, 150).

CRM: it includes the banks that do not have communication channels to provide possibility of recognizing e-CRM for customers (Sivarax and et al. 2011, 151). 
Features of Customer-Based Services: there is a huge gap between the implementation of e-CRM and outcomes. So, there must be something that connects them together(Sivarax and et al. 2011, 149).

Quality of Communication:it isan appropriate levelof responding to customer's needs along with communication and understand themto how their expectations, goals and wills is done at bank. Customer is dependent on complete relationships that he has with the business and it contains various exchanges (Sivarax and et al. 2011, 149).

\section{Studying e-crm and crm}

It has not provided an acceptable definition for CRM, although it is widely known. Definition and field of CRM has been provided in previous researches; recently, Brash \& Bradshaw have found that companies get more efficient by expanding online marketing communications.

Studying the works related to CRM shows that the different research of e-CRM is frequently defined as an integral part of distribution and online marketing that develop CRM conventional techniques with completing technologies of new electronic channels such as web, wireless devices and voice technologies and integrate them with implementations of ecommerce. In addition, Dyche (2011) suggested that there are two main types of e-CRM: Operational and Analytical.

Operational e-CRM pays to the features of contact with customers;in another word, all methods of contact with customer including contact among people, web sites, email, telephone, direct selling and fax. E-CRM is an analysis based on the use of technology in processing and understanding of large amount of customers' data.

Kraft (2000) notes that integration between CRM systems and their allowed systems is very common and the integration of all channels in addition to all the restrictions are necessary for success of company. Due to the significant role of operational e-CRM, Anon (2002) and Kennedy (2006) attempted to spread the subject including electronic channels and technologies such as cell phones, customer's contact centers, voice responding systems that providesthe opportunity to exchange with customers without personal contacting or generally with reduction of human exchange levels (Sivrax and et al. 2012, 148).

\section{Studying e-crm customer benefits}

Advantages of organizational implementation of e-CRM rather than its interactive marketing services are quick services and responding time.

Pan (2003) studies CRM explained CRM on three aspects:

Technology, business and customer 
To study the customer's view, content analysis is implemented to group data:

1- Transferring of services and products at the right time through the right way

2- The multiple interactive value-added customer points with the organization

3- customer's reaction

4- customer's recognition and biography

While CRM is run in business, it's expected that the most benefits caused by implementation of CRM be in the field of quality and outcome of relationship with customer (Sivrax and et al 2011, 146).

\section{Literature review of researches done in and out of country}

Hosseini and et al. in their research done in 2010, titled "Studying and Measuring the Quality Service and its Relationship with Customer's Satisfaction; Case Study: Tejarat Bank) aim to study measuring of customer satisfaction of bank services through Servperf Scale and then they study the relationship between the components of quality service with customer satisfaction. The model presentred by Hosseini and et al. includes six components. Quality service variable with components including (confidence, sensible factors, trust, responding and sympathy) are independent variables of the research. In this regard, six hypotheses have been designed. On the other hand, customer satisfaction variable is the only independent variable of the research. According to the relationships of model, six hypotheses have been designed and studied. As mentioned above, statistical population of this research is Tejarat Bank branches of Karaj City. The questionnaire is used in order to collect data. Among the distributed questionnaires, 250 ones has been completed. Then, the collected data has been analyzed in order to test the hypotheses using Pearson Correlation Method. The results of research show that all variables (confidence, sensible factors, trust, responding and sympathy) have a positive and significant relationship with satisfaction variable. All hypotheses designed in this research has been accepted.

Kasim and Abdollah in their research done in 2010 in two Malaysia and Qatar countries, titled "Studying the Effect of Perceived Quality Service Aspects on Customer's Trust and Loyalty in Tejarat Bank" aim to study the relationship between the perceived services with satisfaction and loyalty in two different culture. The model presented by Kasim and Abdollah is divided into three parts. In first part, the quality service variable is with components including easy use, designing web site, responding, personality and confidence. In this part, all mentioned variables are independent variables of the research. In the second part, two customer satisfaction and confidence variables are intermediary variables. In the third part, 
the customer loyalty variable is the final independent variable that includes components: oral loyalty and maintaining loyaltyintent.

Farughian and et al. in their research done in 2011 in 167 small and medium companies (SME) of Great Britaintitled"Value and Risk in Banking (B2B)" aim to study the role of perceived risk in forming the value of quality service in e-banking services. The model presented by Faroughi and et al. include nine variables. Variables: e-service quality, functional risk, financial risk and mental risk are the independent variables of the research that in this regard, eight hypotheses have been designed. On the other hand, the variables: customers'perceive of sacrifice, customers'perceiveof benefits, customer satisfaction, customer's loyalty and intent of transferring are the dependent variables of the research. Sixteen hypotheses have been studied based on relationships of model. As mentioned above, the statistical population of the research is 167 companies (SME) and the questionnaire is used in order to collect the data.

Udo and et al. in their research done in America in 2010 titled "Assessment of Customers' Perceive of E-Service Quality, Satisfaction and their Behavioral Intent"aim to study the aspects of service quality based on the customers' expectations and impression. The model presented by Udo and et al. includes seven variables. In presented model, variables: perceived risk, content of web site, convenience of services, personal skill are the independent variables and the variables: internet service quality, behavioral intent and customer satisfaction are the dependent variables of the research. The model presented by Udo and et al. studies 10 hypotheses. The information needed for studying and test the research hypotheses is collected through questionnaire by 211 students at State University of America. It is studied and analyzed using structural equations.

\section{RESEACRCH METHOD}

In terms of method, this research is descriptive-correlational and the research method is applied based on the goal. In this study, the field method is used on the regard of collecting the data related to the test of research hypotheses. In this research, the questionnaire has used to collect the data. The questionnaire used in this research includes 23 questions related to the main goal of the research. The answers are designed through Sivrax and et al. article in 2011. The statistical population of research include all staff working at Refah Bank of Arak City. They are 23 people. Based on Morgan Table, the sample size is 80 people. 


\section{DATA ANALYSIS}

1- Implementation of E-CRM has obviously a positive relationship with the features based on customer service.

Table 1. Correlation Coefficient of E-CRM Implementation and features based on customer service

\begin{tabular}{|c|c|c|c|}
\hline & & $\begin{array}{l}\text { Implementation of E- } \\
\text { CRM }\end{array}$ & $\begin{array}{l}\text { features based on } \\
\text { customer service }\end{array}$ \\
\hline \multirow[t]{3}{*}{$\begin{array}{l}\text { Implementation of E- } \\
\text { CRM }\end{array}$} & $\begin{array}{c}\text { Spearman correlation } \\
\text { Coefficient }\end{array}$ & 1 & 0.965 \\
\hline & Sig & & 0.000 \\
\hline & $\mathrm{N}$ & 80 & 80 \\
\hline \multirow[t]{3}{*}{$\begin{array}{l}\text { features based on } \\
\text { customer service }\end{array}$} & $\begin{array}{c}\text { Spearman correlation } \\
\text { Coefficient }\end{array}$ & 0.965 & 1 \\
\hline & Sig & 0.000 & \\
\hline & $\mathrm{N}$ & 80 & 80 \\
\hline
\end{tabular}

The relationship between twovariables, implementation ofE-CRM and features based on customer service, show that $\mathrm{r}=0.965$ and $\operatorname{sig}=0<0.01$. So, the lack of correlation relationship ofE-CRM implementation hypothesis and features based on customer service is denied and the researcher's hypothesis is approved.

1-1 implementation ofE-CRM has a positive relationship with the information received by customer.

Table 2. Correlation Coefficient ofE-CRM Implementation and the information received by customer

\begin{tabular}{|c|c|c|c|}
\hline & & $\begin{array}{l}\text { Implementation of E- } \\
\text { CRM }\end{array}$ & $\begin{array}{l}\text { information received } \\
\text { by customer }\end{array}$ \\
\hline \multirow[t]{3}{*}{$\begin{array}{l}\text { Implementation of E- } \\
\text { CRM }\end{array}$} & $\begin{array}{c}\text { Spearman correlation } \\
\text { Coefficient }\end{array}$ & 1 & 0.937 \\
\hline & Sig & & 0.000 \\
\hline & $\mathrm{N}$ & 80 & 80 \\
\hline \multirow[t]{3}{*}{$\begin{array}{l}\text { information received } \\
\text { by customer }\end{array}$} & $\begin{array}{c}\text { Spearman correlation } \\
\text { Coefficient }\end{array}$ & 0.937 & 1 \\
\hline & Sig & 0.000 & \\
\hline & $\mathrm{N}$ & 80 & 80 \\
\hline
\end{tabular}

The relationship between twovariables, implementation ofE-CRM andinformation received by customer, show that $\mathrm{r}=0.937$ and $\mathrm{sig}=0<0.01$. So, the lack of correlation relationship ofECRM implementation hypothesis and the information received by customer is denied and the 
researcher's hypothesis is approved. 2-1 implementation ofE-CRM has a positive relationship with the contact channels

Table 3. Correlation Coefficient of E-CRM Implementation and thecontact channels

\begin{tabular}{|c|c|c|c|}
\hline & & $\begin{array}{c}\text { Implementation of E- } \\
\text { CRM }\end{array}$ & contact channels \\
\hline \multirow[t]{3}{*}{$\begin{array}{l}\text { Implementation of E- } \\
\text { CRM }\end{array}$} & $\begin{array}{c}\text { Spearman correlation } \\
\text { Coefficient }\end{array}$ & 1 & 0.985 \\
\hline & Sig & & 0.000 \\
\hline & $\mathrm{N}$ & 80 & 80 \\
\hline \multirow[t]{3}{*}{ contact channels } & $\begin{array}{c}\text { Spearman correlation } \\
\text { Coefficient }\end{array}$ & 0.985 & 1 \\
\hline & Sig & 0.000 & \\
\hline & $\mathrm{N}$ & 80 & 80 \\
\hline
\end{tabular}

The relationship between twovariables, implementation ofE-CRM andthe contact channels, show that $\mathrm{r}=0.985$ and $\mathrm{sig}=0<0.01$. So, the lack of correlation relationship ofE-CRM implementation hypothesis and thecontact channels is denied and the researcher's hypothesis is approved.

3-1 implementation ofE-CRM has a positive relationship with customer's convenience

Table 4. Correlation Coefficient ofE-CRM Implementation and thecontact channels

\begin{tabular}{|c|c|c|c|}
\hline & & $\begin{array}{l}\text { Implementation of E- } \\
\text { CRM }\end{array}$ & $\begin{array}{l}\text { customer's } \\
\text { convenience }\end{array}$ \\
\hline \multirow[t]{3}{*}{$\begin{array}{l}\text { Implementation of E- } \\
\text { CRM }\end{array}$} & $\begin{array}{c}\text { Spearman correlation } \\
\text { Coefficient }\end{array}$ & 1 & 0.951 \\
\hline & Sig & & 0.000 \\
\hline & $\mathrm{N}$ & 80 & 80 \\
\hline \multirow[t]{3}{*}{$\begin{array}{l}\text { customer's } \\
\text { convenience }\end{array}$} & $\begin{array}{c}\text { Spearman correlation } \\
\text { Coefficient }\end{array}$ & 0.951 & 1 \\
\hline & Sig & 0.000 & \\
\hline & $\mathrm{N}$ & 80 & 80 \\
\hline
\end{tabular}

The relationship between twovariables, implementation ofE-CRM andthecustomer's convenience, show that $r=0.951$ and sig $=0<0.01$. So, the lack of correlation relationship ofECRM implementation hypothesis and thecustomer's convenienceis denied and the researcher's hypothesis is approved.

2- Implementation ofE-CRM obviously has a positive relationship with quality and outcomes of bank-customer relationships. 
Table 5. Correlation Coefficient ofE-CRM Implementation and quality and outcomes of bank-customer relationships

\begin{tabular}{|c|c|c|c|}
\hline \multirow{2}{*}{$\begin{array}{c}\text { Implementation of E- } \\
\text { CRM }\end{array}$} & $\begin{array}{c}\text { Implementation of E- } \\
\text { CRM }\end{array}$ & $\begin{array}{l}\text { quality and outcomes } \\
\text { of bank-customer } \\
\text { relationships }\end{array}$ \\
\cline { 2 - 4 } & $\begin{array}{c}\text { Spearman correlation } \\
\text { Coefficient }\end{array}$ & 1 & 0.968 \\
\cline { 2 - 4 } & Sig & N & 0.000 \\
\hline \multirow{2}{*}{$\begin{array}{c}\text { quality and outcomes } \\
\text { of bank-customer } \\
\text { relationships }\end{array}$} & $\begin{array}{c}\text { Spearman correlation } \\
\text { Coefficient }\end{array}$ & 0.968 & 80 \\
\cline { 2 - 4 } & Sig & 0.000 & 1 \\
\cline { 2 - 4 } & $\mathrm{N}$ & 80 & 80 \\
\hline
\end{tabular}

The relationship between twovariables, implementation ofE-CRM andthequality and outcomes of bank-customer relationships, show that $r=0.968$ and sig $=0<0.01$. So, the lack of correlation relationship ofE-CRM implementation hypothesis and thequality and outcomes of bank-customer relationships is denied and the researcher's hypothesis is approved.

2-1 Implementation of E-CRM obviously has a positive relationship with general quality of bank-customer relationships.

Table 6. Correlation Coefficient ofE-CRM Implementation andgeneral quality of bankcustomer relationships

\begin{tabular}{|c|c|c|c|}
\hline & & $\begin{array}{l}\text { Implementation of E- } \\
\text { CRM }\end{array}$ & $\begin{array}{l}\text { general quality of } \\
\text { bank-customer } \\
\text { relationships }\end{array}$ \\
\hline \multirow[t]{3}{*}{$\begin{array}{l}\text { Implementation of E- } \\
\text { CRM }\end{array}$} & $\begin{array}{c}\text { Spearman correlation } \\
\text { Coefficient }\end{array}$ & 1 & 0.989 \\
\hline & Sig & & 0.000 \\
\hline & $\mathrm{N}$ & 80 & 80 \\
\hline \multirow{3}{*}{$\begin{array}{l}\text { general quality of } \\
\text { bank-customer } \\
\text { relationships }\end{array}$} & $\begin{array}{c}\text { Spearman correlation } \\
\text { Coefficient }\end{array}$ & 0.989 & 1 \\
\hline & Sig & 0.000 & \\
\hline & $\mathrm{N}$ & 80 & 80 \\
\hline
\end{tabular}

The relationship between twovariables, implementation ofE-CRM andgeneral quality of bank-customer relationships, show that $\mathrm{r}=0.989$ and $\mathrm{sig}=0<0.01$. So, the lack of correlation relationship ofE-CRM implementation hypothesis and general quality of bank-customer relationships is denied and the researcher's hypothesis is approved.

2-2 Implementation ofE-CRM obviously has a positive relationship with customer's trust. 
Table 7. Correlation Coefficient ofE-CRM Implementation andcustomer's trust

\begin{tabular}{|c|c|c|c|}
\hline \multirow{4}{*}{$\begin{array}{c}\text { Implementation of E- } \\
\text { CRM }\end{array}$} & $\begin{array}{c}\text { Implementation of E- } \\
\text { CRM }\end{array}$ & customer's trust \\
\cline { 2 - 4 } & Spearman correlation & 1 & 0.966 \\
\cline { 2 - 4 } & Sig & & 0.000 \\
\hline customer's trust & $\begin{array}{c}\text { Spearman correlation } \\
\text { Coefficient }\end{array}$ & 0.966 & 80 \\
\cline { 2 - 4 } & Sig & 0.000 & 1 \\
\cline { 2 - 4 } & $\mathrm{N}$ & 80 & 80 \\
\hline
\end{tabular}

The relationship between twovariables, implementation ofE-CRM andcustomer's trust, show that $r=0.989$ and $\operatorname{sig}=0<0.01$. So, the lack of correlation relationship ofE-CRM implementation hypothesis and customer's trust is denied and the researcher's hypothesis is approved.

2-3 Implementation ofe-customer relationship management withcustomercommitment.

Table 8. Correlation Coefficient ofE-CRM Implementation andcustomer commitment

\begin{tabular}{|c|c|c|c|}
\hline \multirow{3}{*}{$\begin{array}{c}\text { Implementation of E- } \\
\text { CRM }\end{array}$} & $\begin{array}{c}\text { Implementation of E- } \\
\text { CRM }\end{array}$ & customercommitment \\
\cline { 2 - 4 } & Spearman correlation & 1 & 0.948 \\
\cline { 2 - 4 } & Sig & & 0.000 \\
\hline customercommitment & $\begin{array}{c}\text { Spearman correlation } \\
\text { Coefficient }\end{array}$ & 0.948 & 80 \\
\cline { 2 - 4 } & Sig & 0.000 & 1 \\
\cline { 2 - 4 } & $\mathrm{N}$ & 80 & 80 \\
\hline
\end{tabular}

The relationship between twovariables, implementation ofE-CRM andcustomercommitment, show that $\mathrm{r}=0.948$ and sig $=0<0.01$. So, the lack of correlation relationship ofE-CRM implementation hypothesis and customersatisfaction is denied and the researcher's hypothesis is approved. 2-4 Implementation ofe-customer relationship management with customer satisfaction. 
Table 9. Correlation Coefficient ofE-CRM Implementation andcustomer satisfaction

\begin{tabular}{|c|c|c|c|}
\hline \multirow{4}{*}{$\begin{array}{c}\text { Implementation of E- } \\
\text { CRM }\end{array}$} & $\begin{array}{c}\text { Implementation of E- } \\
\text { CRM }\end{array}$ & customer satisfaction \\
\cline { 2 - 4 } & Coefficient & 1 & 0.935 \\
\cline { 2 - 4 } & Sig & & 0.000 \\
\hline customer satisfaction & $\begin{array}{c}\text { Spearman correlation } \\
\text { Coefficient }\end{array}$ & 0.935 & 80 \\
\cline { 2 - 4 } & Sig & 0.000 & 1 \\
\cline { 2 - 4 } & $\mathrm{N}$ & 80 & 80 \\
\hline
\end{tabular}

The relationship between twovariables, implementation ofE-CRM andcustomercommitment, show that $\mathrm{r}=0.935$ and sig $=0<0.01$. So, the lack of correlation relationship ofE-CRM implementation hypothesis and customersatisfaction is denied and the researcher's hypothesis is approved. 2-5 Implementation ofe-customer relationship management with customer loyalty.

Table 10. Correlation Coefficient ofE-CRM Implementation andcustomer loyalty

\begin{tabular}{|c|c|c|c|}
\hline & & $\begin{array}{l}\text { Implementation of E- } \\
\text { CRM }\end{array}$ & customer loyalty \\
\hline \multirow[t]{3}{*}{$\begin{array}{c}\text { Implementation of E- } \\
\text { CRM }\end{array}$} & $\begin{array}{c}\text { Spearman correlation } \\
\text { Coefficient }\end{array}$ & 1 & 0.962 \\
\hline & Sig & & 0.000 \\
\hline & $\mathrm{N}$ & 80 & 80 \\
\hline \multirow[t]{3}{*}{ customer loyalty } & $\begin{array}{c}\text { Spearman correlation } \\
\text { Coefficient }\end{array}$ & 0.962 & 1 \\
\hline & Sig & 0.000 & \\
\hline & $\mathrm{N}$ & 80 & 80 \\
\hline
\end{tabular}

The relationship between twovariables, implementation ofE-CRM andcustomerloyalty, show that $r=0.962$ and $\operatorname{sig}=0<0.01$. So, the lack of correlation relationship ofE-CRM implementation hypothesis and customerloyalty is denied and the researcher's hypothesis is approved.

3- Implementation of E-CRM has an indirect effect on quality-income relationship through the features of customer-based services.

First, the effect and relationship of E-CRM implementation on the features of customer-based services is studied that in hypothesis 1 , it issue is approved with correlation coefficient 0.965 , then the effect and relationship ofthe features of customer-based services on the quality and outcomes of bank-customer relationships is studied. 
Table 11. Correlation Coefficient ofthe features of customer-based servicesand the quality and outcomes of bank relationships

\begin{tabular}{|c|c|c|c|}
\hline \multirow{4}{*}{$\begin{array}{c}\text { Implementation of E- } \\
\text { CRM }\end{array}$} & $\begin{array}{c}\text { Implementation of E- } \\
\text { CRM }\end{array}$ & $\begin{array}{c}\text { quality and outcomes } \\
\text { of bank relationships }\end{array}$ \\
\cline { 2 - 4 } & $\begin{array}{c}\text { Spearman correlation } \\
\text { Coefficient }\end{array}$ & 1 & 0.972 \\
\cline { 2 - 4 } & Sig & & 0.000 \\
\hline \multirow{2}{*}{$\begin{array}{c}\text { quality and outcomes } \\
\text { of bank relationships }\end{array}$} & $\begin{array}{c}\text { Spearman correlation } \\
\text { Coefficient }\end{array}$ & 0.972 & 80 \\
\cline { 2 - 4 } & Sig & 0.000 & 1 \\
\cline { 2 - 4 } & $\mathrm{N}$ & 80 & 80 \\
\hline
\end{tabular}

The relationship between twovariables, the features of customer-based servicesandthe quality and outcomes of bank relationships, show that $r=0.972$ and sig $=0<0.01$. So, the lack of correlation relationship ofthe features of customer-based servicesandthe quality and outcomes of bank relationshipshypothesis is approved.

Table 12. regression equationcoefficients of regression test with dependent variable of quality and outcomes of bank-customer relationships

\begin{tabular}{|c|c|c|c|c|c|}
\hline \multirow{2}{*}{ model } & \multicolumn{2}{|c|}{$\begin{array}{c}\text { Unstandardized } \\
\text { confilcents }\end{array}$} & $\begin{array}{c}\text { Standardized } \\
\text { coefilclents }\end{array}$ & sig \\
\cline { 2 - 6 } & B & Std.Error & & -30.842 & 0.001 \\
\hline $\begin{array}{c}\text { Fixed } \\
\text { amount }\end{array}$ & -0.243 & 0.089 & & 44.462 & 0.000 \\
\hline $\begin{array}{c}\text { features of } \\
\text { customer- } \\
\text { based } \\
\text { services }\end{array}$ & 1.049 & 0.024 & 0.981 & \\
\hline
\end{tabular}

$$
\hat{\mathrm{y}}=-0.243+981 X_{26}
$$

According to significance level for regression coefficient of quality and outcomes of bankcustomer variable ( $\mathrm{sig}=0.00<0.05$ ) null hypothesis of zero value will be denied. As a result, it can be said that for one unit add to customer-based services, quality and outcomes of bankcustomer relationships will increase to 0.981 unit (because of positive regression coefficient) and given that regression coefficient will be significant, so the researcher's hypothesis based on the effect and relationship between the features of customer-based services and quality outcomes of bank-customer relationships with confidence level 95\% is approved. On the other words, there is a positive relationship between the features of customer-based services 
and quality outcomes of bank-customer relationships. Given that the effect of E-CRM implementation on the features of customer-based services and quality and outcomes of bankcustomer relationships is 0.981 (correlation coefficient 0.972 ), so the indirect effect of ECRM implementation on quality and outcomes of bank-customer relationships through the features of customer-based services are $0.959,0.981$ and 0.978 also, the their relationships are $0.950,0.965$ and 0.972

\section{CONCLUSION BASED ON HYPOTHESES}

The previous studies and interviewing with experts showed that there is a huge gap between e-CRM and outcomes, so there must be something to connect them together. Studying of the other workshave defined features of customer-based services as the structure connector. In this study,the features of customer-based services is defined as activities of CRM and e-CRM services. Therelated structures of customer-based service activities and outcomes of e-CRM has been obtained using the information obtained by experts and previous studies.

\section{1- Implementation of E-CRM has obviously a positive relationship with the features based on customer service.}

Spearman correlation coefficient is 0.965 ; on the other hand, due to the researcher's positive hypothesis based on the effect and relationship of E-CRM implementation and features based on customer services, is approved. The results of analyzing this factor show that it can be grouped according to three factors: information, convenience and connect channels.

\section{1-1 E-CRM has a positive relationship with the information received by customer.}

Spearman correlation coefficient is 0.985 ; on the other hand, due to the researcher's positive hypothesis based on the effect and relationship of E-CRM implementation andthe information received by customer, is approved. The results of this study is the same with the results of studies done by Mayson and et al. in 2011.

\section{1-2 implementation of E-CRM has a positive relationship with the customer's contact channels.}

Spearman correlation coefficient is 0.985 ; on the other hand, due to the researcher's positive hypothesis based on the effect and relationship of E-CRM implementation andthe customer's contact channels, is approved.

\section{1-3 implementation of E-CRM has a positive relationship with customer's convenience.}

Spearman correlation coefficient is 0.951 ; on the other hand, due to the researcher's positive hypothesis based on the effect and relationship of E-CRM implementation andthe customer's convenience, is approved. 
2- Implementation of E-CRM obviously has a positive relationship with quality and outcomes of bank-customer relationships.

Spearman correlation coefficient is 0.968 ; on the other hand, due to the researcher's positive hypothesis based on the effect and relationship of E-CRM implementation andthequality and outcomes of bank-customer relationships, is approved.The results of this study is the same with the results of studies done by Sivrax and et al. (2011) and Kim (2006). Kim's results show that there is a direct relationship between relationship quality and the relationship outcome.

2-1 Implementation of E-CRM obviously has a positive relationship with general quality of bank-customer relationships.

Spearman correlation coefficient is 0.989 ; on the other hand, due to the researcher's positive hypothesis based on the effect and relationship of E-CRM implementation andthegeneral quality of bank-customer relationships, is approved.

\section{2-2 Implementation of E-CRM obviously has a positive relationship with customer's} trust.

Spearman correlation coefficient is 0.966 ; on the other hand, due to the researcher's positive hypothesis based on the effect and relationship of E-CRM implementation andthecustomer's trust, is approved.

2-3 Implementation of E-CRM obviously has a positive relationship with customersatisfaction.

Spearman correlation coefficient is 0.935 ; on the other hand, due to the researcher's positive hypothesis based on the effect and relationship of E-CRM implementation andthecustomer satisfaction, is approved.

2-4Implementation of E-CRM obviously has a positive relationship with customercommitment.

Spearman correlation coefficient is 0.948 ; on the other hand, due to the researcher's positive hypothesis based on the effect and relationship of E-CRM implementation andthecustomer commitment, is approved.

2-5Implementation of E-CRM obviously has a positive relationship with customerloyalty.

Spearman correlation coefficient is 0.976 ; on the other hand, due to the researcher's positive hypothesis based on the effect and relationship of E-CRM implementation andthecustomer loyalty, is approved. 


\section{2-6Implementation of E-CRM obviously has a positive relationship with customerrecommendations.}

Spearman correlation coefficient is 0.962 ; on the other hand, due to the researcher's positive hypothesis based on the effect and relationship of E-CRM implementation andthecustomer recommendations, is approved.

\section{3- Implementation of E-CRM has an indirect effect on quality-income relationship through the features of customer-based services.}

Spearman correlation coefficient is 0.972 ; on the other hand, due to the researcher's positive hypothesis based on the effect and relationship of features customer-based services, is approved. The results of this study is the same with the results of study done by Sivrax and et al. (2012). The results of Sivrax's study shows that there is a direct and positive effect on quality and also there is an indirect and positive effect on outcome.

Sivrax and et al. studied the effects of the relationship marketing activities on the relationship outcomes: satisfaction and customer loyalty.

It seems that due to internet bank services is new in our country and the users have not been enough trained for this issue. On the other hands, the efficiency of this type of systems is low in our country due to the lack of appropriate organizing and adequate flexibility in bank web sites in order to offer better, complete and quick services.

\section{Suggestions based on hypotheses}

Hypothesis 1: it is suggested that the commerce banks know e-CRM technologies very well and the most implementations of e-CRM be in the field of analysis; so it needs to collect enough information from the customers.

Hypothesis 2: it is suggested the banks provide the condition that the customers receive the right information on time and the banks offer their main information to the customers and customers can receive their updated information from their main banks.

Hypothesis 3: the most respondents do not connect to their main banks through the electronic channels, so it should be considered the customers' views in the field of e-CRM implementation. 


\section{REFRENCES}

- Hosseini M.H, Ahmadinejad M. and Ghaderi S. "Studying and Measuring the Service Quality and its Relationship with Customers Satisfaction (case study: Tejarat Bank)" commercial studies, 2010, 42

- Zitamelvaleri A. and Parasorman translated by Heydarzade K. and Hajiha A. (2008) "service quality ofanalyzing Servqual's model and offering the new models" KasaKavosh Publication, $1^{\text {st }}$ Edit

- Nayebzade S. and Fatahi M. M. "assessment of service quality in police=10 offices using Servqual's model", Marketing Management Journal, $4^{\text {th }}$ year, 2009, 7

- Anon, J. Unravelling eCRM. CRM Market Watch, 2002, 28: 12-13.

- Bradshaw, D., \& Brash, C. Managing customer relationships in the e-business world: How to personalize computer relationships for increased profitability.International Journal of Retail and Distribution Management, 2001, 29(5): 520-529.

- Doherty,N\&Chadwick,F , "Exploring the drivers, scope and perceived success of ecommerce strategies in the UK retail sector" , European Journal of Marketing , 2008, 43 (9/10): 1246-1262.

- Dyche, J. (2001). The CRM handbook: A business guide to customer relationship management. Boston: Addison-Wesley.

- Faroughian,F, Stavros P. Kalafatis, Lesley Ledden, Phillip Samouel\&Markos H. Tsogas ," Value and risk in business-to-business e-banking" , Industrial Marketing Management 2011, 41: 68-81.

- Feinberg, R., \&Kadam, R. E-CRM Web service attributes as determinants of customer satisfaction with retail Web sites. International Journal of ServiceIndustry Management, 2002, 13(5): 432-451.

- Hu,Yi-Chung \& Liao P,Finding critical criteria of evaluating electronic service quality of Internet banking using fuzzy multiple-criteria decision making",Applied Soft Computing 2011, 11: 764-3770.

- Kassim,N, \& Nor Asiah Abdullah,"The effect of perceived service quality dimensions on customer satisfaction, trust, and loyalty in e-commerce settings" , Asia Pacific Journal of Marketing and Logistics, 2010, 22(3): 351-371.

- Kennedy (2006). Electronic Customer Relationship Management (eCRM): Opportunities and challenges in a digital world. Irish Marketing Review, 18.

- Kraft, K.. Loyalty on the line. Intelligent Enterprise, 2000, 3(17). 
- Pan, S. L., \& Lee, J. N. Using e-CRM for a unified view of the customer. Communications of the ACM, 2003, 46: 95-99.

- Rasheed,M, \&Latif ,A , "Does Technology-Enabled Service Quality affect Organizational Competencies?" , Journal of Public Administration and Governance, ISSN 2161-7104, 2011, 1(2): 58-76.

- Sheng,T\&Liu,C, "An empirical study on the effect of e-service quality on online customer satisfaction and loyalty" , Nankai Business Review International , 2010, 1(3): 273-283.

- Shin-Ping, T, "E-commerce standard user interface: an E-menu system", Industrial Management \& Data Systems, 2008, 108(8): 1009-1028.

- Savarins. P., Kraits, D., Tang, J. "Effects of e-CRM on customer-bank relationship quality and outcomes: The case of Thailand", Journal of high technology management research, 2012, 22: 141- 157.

- Toyin A. Clottey, David A. Collier, \& Michael Stodnick, "Drivers Of Customer Loyalty In A Retail Store Environment", Journal of Service Science, 2008, 1(1): 3548.

- Udo,G, Kallol K. Bagchi\&Peeter J. Kirs ,"An assessment of customers' e-service quality perception, satisfaction and intention", International Journal of Information Management, 2010, 30: 481-492.

\section{How to cite this article:}

Farahani M G, Eaidivandi M A, Rad H Z. Studying theelectroniccustomer relationship management and its effect on bank quality outcomes. J. Fundam. Appl. Sci., 2016, 8(2S), $1709-1725$. 